Int. J. Electrochem. Sci., 15 (2020) 11238 - 11249

International Journal of

ELECTROCHEMICAL

SCIENCE

$\underline{\text { www.electrochemsci.org }}$

\title{
Gold/Copper-Based Metal-Organic Framework/Glassy Carbon Electrode as High Efficient Electrochemical Sensor for Determination of Hydrogen Peroxide
}

\author{
Danfeng He ${ }^{1}$, Fujiang Zhou ${ }^{2}$, Liqun Sun ${ }^{1}$, Yanbin Tong ${ }^{1}$, Long Tang ${ }^{1, *}$, Zhicheng Zhong ${ }^{3}$, Hongqin Li ${ }^{3}$ \\ ${ }^{1}$ Heilongjiang Provincial Key Laboratory of Oilfield Applied Chemistry and Technology, Daqing \\ Normal University, Daqing 163712, China \\ ${ }^{2}$ Daqing Oileld Chemical Corporation, Daqing, Heilongjiang, 163712, China \\ ${ }^{3}$ College of Instrumentation and Electrical Engineering, Jilin University, Changchun 130012, China \\ "E-mail: tanglong088@163.com and choubuzhongjiang@163.com
}

doi: $10.20964 / 2020.11 .04$

Received: 2 June 2020 / Accepted: 23 August 2020 / Published: 30 September 2020

In this study, the modified gold/copper-based metal-organic framework on glassy carbon electrodes [( $\left.\mathrm{Au}_{\mathrm{x}}: \mathrm{Cu}_{\mathrm{y}}\right)-\mathrm{MOF} / \mathrm{GCE}(\mathrm{x}, \mathrm{y}=0,1,2$ and 3 as volume ratio)] were applied for electrochemical determination of hydrogen peroxide $\left(\mathrm{H}_{2} \mathrm{O}_{2}\right)$. $\left(\mathrm{Au}_{\mathrm{x}}: \mathrm{Cu}_{\mathrm{y}}\right)$-MOFs were synthesized through the oriented growth method and were applied to modification of GCE. SEM and XRD analyses were employed to structural studies of synthesized $\left(\mathrm{Au}_{\mathrm{x}}: \mathrm{Cu}_{\mathrm{y}}\right)$-MOFs. Cyclic voltammetry and amperometry techniques were used to electrochemical characterization of $\left(\mathrm{Au}_{\mathrm{x}}\right.$ : $\left.\mathrm{Cu}_{\mathrm{y}}\right)-\mathrm{MOFs} / \mathrm{GCE}$ as $\mathrm{H}_{2} \mathrm{O}_{2}$ sensor. Results showed that $\left(\mathrm{Au}_{\mathrm{x}}: \mathrm{Cu}_{\mathrm{y}}\right)$-MOFs were synthesized in porous and densely packed irregular nano-sheet structure. The electrochemical studies showed that $\left(\mathrm{Au}_{1}: \mathrm{Cu}_{2}\right)-\mathrm{MOF} / \mathrm{GCE}$ was fast response, sensitive, stable and selective sensor for the determination of $\mathrm{H}_{2} \mathrm{O}_{2}$. The wide linear range, sensitivity and detection limit of the sensor were estimated of 1 to $19 \mu \mathrm{M}, 2.022 \mu \mathrm{A} / \mu \mathrm{M}$ and $0.014 \mu \mathrm{M}$, respectively. Comparison performance $\left(\mathrm{Au}_{1}: \mathrm{Cu}_{2}\right)-\mathrm{MOF} / \mathrm{GCE}$ with other $\mathrm{H}_{2} \mathrm{O}_{2}$ sensor exhibits higher or comparative sensitivity in determination of $\mathrm{H}_{2} \mathrm{O}_{2}$. Study the sensor response to the determination of $\mathrm{H}_{2} \mathrm{O}_{2}$ in real sample indicated satisfactory RSD and recovery values was less than $4.51 \%$ and more than $91.86 \%$, respectively.

Keywords: Hydrogen peroxide; Metal-organic framework; Amperometry technique; Sensitivity and selectivity electrochemical sensor

\section{$\underline{\text { FULL TEXT }}$}

(C) 2020 The Authors. Published by ESG (www.electrochemsci.org). This article is an open access article distributed under the terms and conditions of the Creative Commons Attribution license (http://creativecommons.org/licenses/by/4.0/). 